\title{
DE LA AGRESIÓN A LAS PALABRAS Apuntes para una historia de la violencia política en Chile
}

\author{
CRISTIÁN BARRÍA IROUMÉ
}

\begin{abstract}
RESUMEN: La violencia política en nuestra sociedad chilena no es más que la prolongación del papel de la venganza en la justicia antigua, la figura del juez desaparece en beneficio del poder político, el soberano se convierte en el verdugo y las víctimas que caen bajo su yugo, se transforman en insignificantes individuos absorbidos por la enormidad del poderoso. El vehículo para pensar nuestra violencia, es la historia, a partir de ella analizaremos cómo ha ocurrido antes y en otros lugares, y a su vez, cómo es abandonada y superada por las palabras, lenguaje que importa el respeto de la comunidad humana, a lo razonable y verdadero.
\end{abstract}

Palabras clave: Violencia politica, poder, verdugo-soberano, revoluciones, muerte, palabras.

ABSTRACT: Political violence in the Chilean society is merely an extension of the role of revenge in ancient justice, the figure of the judge disappears in favour of political power, the sovereign becomes the executioner, and the victims who fall under his yoke, become insignificant individuals absorbed by the enorrmity of the powerful. The vehicle for thinking about our violence is History; from which we will analyze how it has occurred before and elsewhere, and in turn, how it's abandoned and overtaken by the words, language that implies respect of human community to what's reasonable and true.

Key words: Political violence, power, sovereign-executioner, revolution, death, words.

"Nuestras instituciones politicas y religiosas tanto como nuestras ciudades de piedra y hierro reposan sobre lo más frágil y evanescente: sonidos que son sentido. Una metáfora: el pacto verbal, es el fundamento de nuestras sociedades".

Octavio Paz

\section{PRESENTACIÓN}

\section{UNA ARQUEOLOGÍA DE LA VIOLENCIA}

La experiencia de violencia política en Chile es una herida reciente que tomará quizá generaciones en cicatrizarse. Los estudios sobre ella arrojan alguna luz pero siempre parecen dejar algo esencial en la sombra: hay algo de enigmático en ella. La capacidad del hombre para transformarse en enemigo de otro hombre es notable y desconcertante. Quizá la violencia es demasiado reciente como para ser capaces de hablar de ella. El miedo, la pena, el espanto o la ira, todavía nos poseen demasiado intensamente. Mirar nuestra historia es una tarea ardua y necesaria. Legamos a los jóvenes un país herido y no

\footnotetext{
* Médico psiquiatra (U. de Chile), ex docente de Psicología Comunitaria en U. de Chile (profesor asistente). Miembro de institución que asiste a víctimas de violaciones a sus derechos humanos y sus familias (ILAS, Instituto de Salud Mental y Derechos Humanos).
} 
podemos renunciar a proponerles un diagnóstico de lo vivido. La democracia exige llegar al fondo de nuestras prácticas no democráticas del pasado reciente.

La violencia ha estado entre nosotros por muchos años con su presencia pesada, impregnando los hábitos de la vida nacional, como si un animal hubiera asolado la región, dejando sus trazas y dejando incluso en nuestros gestos una cautela, una intuitiva reacción de defensa. Intentaremos recordar esa fiera que al parecer se ha ido. No es fácil dibujar su imagen. ¿Cuál era su perfil, su anatomía? ¿Cuáles sus caminos y madrigueras? ¿Qué alimentos la nutrían? ¿Quiénes sus guardianes y sus amos? Nuestros recuerdos se vuelven borrosos. ¿Será nuestro dolor, nuestra furia lo que nos mella los ojos? Cuesta apresar en nuestras redes una presa tan furtiva, tan maestra en la metamorfosis como la bestia de la violencia. Tal vez no se ha retirado definitivamente y aún permanece por ahí agazapada como un animal semidormido, como si no quisiera darnos reposo definitivo.

Hay un camino para pensar nuestra violencia: la historia. ¿Cómo han ocurrido antes y en otras partes cosas semejantes? En Chile, en ciertos días resultaba más tolerable leer sobre la violencia ejercida en el pasado, que mirar por la ventana. En ese Chile evidentemente no había justicia: vivíamos en la excepción de ella. Me pregunté cómo habría sido antes la justicia, cómo habría nacido la figura de un juez. Todo eso se había perdido en Chile y parecía que el reloj de la historia había retrocedido a una época en la que no existían jueces ni sentencias sino bandos en pugna. La dictadura perseguía a los que creía peligrosos, los exiliaba y diezmaba más allá de las fronteras. ¿Habíamos vuelto a la época de los reyes absolutos que ejecutaban a los conspiradores en la plaza pública para escarmentar a la población en la Edad Media? ¿Cómo era esa época feroz y arcaica de la humanidad que parecía de pronto haber resucitado entre nosotros? La violencia parece siempre volver a los caminos recorridos desde antiguo. Hacer la arqueología de la violencia puede iluminar sus encarnaciones modernas. Encontramos páginas que nos contaban de violencias del pasado y allí íbamos reconociendo rasgos de nuestra propia violencia moderna.

Una anatomía de la violencia que la exponga ante nuestros ojos, nos puede hacer más libres ante la tentación totalitaria que habita en el fondo de todos nosotros. Cuando no recordamos, inevitablemente repetimos. Hace falta recordar para hacerlo distinto en adelante y ser capaces de suspender la agresión y afirmar el derecho a hablar entre nosotros. Cuando golpean la puerta de la casa a las cinco de la mañana y es el lechero, decía Churchill, es que estamos en democracia. En Chile, en miles de casas alguien golpeó la puerta en la noche, y hubo penas y dolores. ¿Quiénes eran esos hombres que golpeaban la puerta?

\section{PINOCHET O EL DELIRIO DEL PODER}

Según Canetti, en el ejercicio del poder existe un grano de locura, un matiz delirante. Ahora bien, en el poder extremo, en el poder totalitario este elemento se desarrolla por completo llegando a constituir un delirio realizado. No es casual que un enfermo paranoico encerrado en el sanatorio se sienta con frecuencia un gran personaje: el emperador, el 
Mesías, el elegido. La locura y el poder tienen en su extremo algo en común. El enfermo en su carencia construye un castillo imaginario: gobierna solo en fantasía y ha caído fuera de la realidad. El verdadero poderoso, en cambio, es eficaz y construye su morada en los hechos: su reino, su ejército. El poderoso hace realidad su sueño. Así el paranoico y el dictador son figuras opuestas pero afines. Son figuras en espejo: fracasado y enfermo, uno; exitoso y realizado, el otro.

Este matiz delirante del poder totalitario, es destacado por Canetti. Habitualmente se nos escapa y aceptamos la realidad como un hecho consumado. Normalmente somos ciegos al elemento de locura inherente al poder. El poder lo sabe, y por eso se permite tantas licencias. El ciudadano cerrará los ojos ante sus excesos y nada verá. O si ve, hará como que nada ha visto. Pues no lo podría creer. Esta complicidad generalizada permite las enormidades del poder. Cuando finalmente el poder se derrumba, muchos descubrimos asombrados lo que no habíamos querido ver. Lo que no queremos ver, dice Canetti, no es otra cosa que la muerte. El poder se afirma en la capacidad de dar muerte a seres humanos. El poder totalitario, simplemente se afirma en la muerte de muchos.

Canetti nos ayuda a entender el enigmático fenómeno del poder, recurriendo al relato de un enfermo, el polo opuesto del poderoso y al mismo tiempo su espejo. Un hombre delirante, Schreber, nos enseña de la esencia del poder. ¿o es acaso un espectáculo delirante ver en los noticiarios de televisión cómo en Chile se excavan tumbas a 30 años de producidas las muertes? Imaginemos un enfermo delirante que afirmara que su país entero es un gigantesco cementerio y que sus habitantes están condenados a excavarlo centímetro a centímetro para encontrar sus muertos, escondidos misteriosamente. Pues bien, en Chile esta afirmación delirante es, al mismo tiempo, verdadera. El país periódicamente observa cómo se excava la tierra, anteayer en el campo y el desierto, ayer en pequeños pueblos de provincia; después en fosas comunes aquí y allá. ¿Cuáles serán mañana? En una perpetua búsqueda de un tesoro extraviado, obreros y expertos criban la tierra extrayendo huesos, depositados cuidadosamente en bolsas a examinar después. ¿Cuál es el signo de que los huesos son los buscados? La noticia lo anuncia: las amarras en las extremidades; las fracturas múltiples; los impactos múltiples de bala. Sorprendentemente, a veces se descubre que los restos no corresponden a los desaparecidos buscados. La noticia se hace aún más delirante: los cuerpos encontrados, al parecer, no han sido reclamados aún, serían desaparecidos no registrados, anónimos. Se avisa por los medios de prensa a personas que ayer callaron, que acudan a reclamar esas víctimas sin identidad. Es el mundo al revés. Restos anónimos salen a la luz, en busca de un nombre, en una ciudad con un nombre significativo: Concepción.

En Chile la realidad se volvió delirante, solo que no lo percibimos por habernos acostumbrado a lo insólito. Los jueces en parte en vez de investigar a los criminales, como es lo habitual, investigan a los muertos. ¿Y cuál es el fruto de su indagación? Estos restos son de Juan; estos, de Pedro. Se trata de reunir un cuerpo, con el nombre que le corresponde. Esto es una ceremonia sagrada para los familiares que peregrinaban sin rumbo. En un parto violento, la tierra da a luz un muerto que puede ser por fin enterrado por quienes lo quieren, para descansar en paz. A veces logran bautizar unos restos con un nombre, a veces después se lo quitan, se habían equivocado. 


\section{Un Gigante PODEROSO}

Canetti describe un rasgo del poder extremo: el poderoso se vuelve un gigante, alrededor del cual los hombres se van empequeñeciendo. El enfermo Schreber en su delirio ilustra este rasgo del poder. Este enfermo sentía que las estrellas eran como las almas de los hombres. Todas las constelaciones de estrellas-almas giraban a su alrededor. Se le acercaban, y en este camino se iban empequeñeciendo. "Se reunían en tropel alrededor de Schreber para luego diluirse en su cabeza o en su cuerpo. De noche goteaban sobre él, desde las estrellas, millares de "hombrecitos" minúsculos, figurillas de forma humana y escasos milímetros de altura que llevaban una breve existencia en su cabeza. Pero muy pronto se acababan: su cuerpo las reabsorbía y ellas se desvanecían en él (...) De este modo se fueron disolviendo constelaciones enteras" ${ }^{1}$. Esta es la locura de un individuo que siente que las almas de los demás se vuelcan en su cuerpo.

En la locura de Chile el poder efectivamente empequeñeció a todos los hombres, excepto a uno: el dictador. Muchos perecieron devorados por el poder, para así engrandecerlo. Como desde las estrellas se desprendían hombrecitos, que atraídos por una fuerza mortal, desaparecían en el cuerpo del gigante Schreber, así murieron tantos, devorados por el poder estatal en Chile. En vez de disolverse en la cabeza del gigante, en la realidad se han disuelto en el mar, en los ríos; están aún disolviéndose en la tierra muchos desaparecidos que nutrieron al poder.

\section{LA TIERRA ES UN CUERPO}

El territorio es un gigante dormido que contiene a los muertos que alimentaron el cuerpo desmesurado del poder. La tierra tiene una relación particular con el poder. El territorio se continúa con el cuerpo del poderoso. En realidad, el poderoso tiene un cuerpo doble. Uno carnal y además uno simbólico: el territorio que rige. El rey es uno con sus tierras. Un ultraje al territorio es una ofensa al cuerpo del soberano. Así, Hitler se identificaba con el territorio alemán: crecía Alemania y era Hitler mismo quien crecía. "Pues todo lo conquistado es para Hitler como un trozo de su propio cuerpo. Su decaimiento físico durante las últimas semanas de Berlín, decaimiento que Speer describe muy detalladamente (...) no es otra cosa que la disminución de su poderío. El cuerpo del paranoico es su poder, y con él medra o se marchita" 2 .

Ayer en Chile, el poder creció al matar a cientos, a miles. Hoy, al extraerse a la luz los cuerpos de los desaparecidos, ese poder por el contrario se marchita. Por eso los poderosos de ayer obstaculizan esta tarea. Perciben que el delirio que ayer los hizo fuertes, se debilita con cada cuerpo que la tierra devuelve hoy día. Ahora esos restos han dejado de alimentar al poder, y se han transformado en cuerpo de delito: los acusan. Las muertes que ayer fueron ofrecidas en salvaje sacrificio al poder, esta vez se revelan como un crimen: víctimas amarradas, asesinadas con saña.

${ }^{1}$ CAnetTi, Elías. La conciencia de las Palabras, 1975.

2 Idem. 
La enormidad del poderoso, su grandeza y desmesura, tal vez expliquen la insignificancia de las demás personas en torno a su figura. Los ministros y secretarios del dictador, resultan siempre pequeños, mínimos. Carecen de voluntad, de fisonomía propia. Son en rigor, nadie. Esta cualidad mortal del héroe afecta no solo a sus enemigos, sino también, a sus colaboradores quienes quedan en la sombra y eclipsados por su presencia arrolladora. El poderoso ríe; todos ríen. El calla; se extiende el silencio. Los hombres que en su entorno muestran capacidad potencial de adquirir poder, son percibidos inmediata y certeramente como enemigos. El héroe los fulmina. En estos regímenes la violencia siempre abate a los potenciales rivales. Muere violentamente un antiguo jefe: Prats. Caen rivales emergentes: Letelier, Leighton. En sus propias filas los potenciales líderes serán arrastrados a un estado de muerte civil, en que ya no representen peligro. Oficiales populares son llamados a retiro; un miembro de la propia Junta de Gobierno es declarado incapaz. Algún alto jefe muere accidentalmente. Un ex presidente muere ¿envenenado? Los rivales caen y su ruina fortalece al amo. Las muertes alimentan el poder.

\section{LA MaGia de LA ViOlenCia}

El primitivo creía que una parte del espíritu de los muertos pasaba al vencedor; es la sabiduría de los indígenas que nos enseña hoy día. Igualmente Canetti muestra una de las fuentes de la fuerza del héroe: la muerte de sus rivales. El guerrero que vence en combates sucesivos se va sintiendo gradualmente invulnerable. "Quien tiene la suerte de vencer, siente aumentar sus propias fuerza (...) Tras una serie de triunfos obtendrá lo más preciado para un combatiente: una sensación de invulnerabilidad (...) Es como si ahora tuviera realmente otro cuerpo, ya no desnudo ni poco resistente, sino acorazado por todos los instantes de sus triunfos. Finalmente nadie puede hacerle nada: es un héroe" ${ }^{3}$. Esta conciencia heroica de pueblos antiguos sobrevive y está muy presente en los uniformados chilenos, que frecuentemente pronuncian orgullosamente, ante los periodistas, la frase "siempre vencedor, jamás vencido". El militar aspira a ser invencible. Es la conciencia del héroe, del titán, del semidiós. ¿Cuándo podrá ser realizada? Es el sueño delirante del poder, que parece repetirse en la historia regularmente.

El poder del guerrero que crece y se fortalece con cada enemigo muerto es expresado claramente en los mitos de pueblos originarios. En la Polinesia, con el nombre mana se designa una especie de poder sobrenatural que puede pasar de un hombre a otro.

"En las Islas Marquesa (...), se suponía que el guerrero acumulaba en su propio cuerpo el mana de todos aquellos a quienes había dado muerte. Su propio mana aumentaba en proporción a su valentía (...) El vencedor en un combate cuerpo a cuerpo adoptaba después el nombre del enemigo abatido, lo cual era signo de que su poder le pertenecía a partir de ese momento. Para asimilar directamente el mana del vencido, comía su carne, y para fijar a su persona dicho aumento de poder durante una batalla, para asegurarse una relación íntima con el mana capturado,

3 Idem. 
llevaba consigo, como parte de sus avío de guerra, cualquier resto corporal del enemigo vencido: un hueso, una mano desecada, a veces incluso un cráneo entero" ${ }^{\text {. }}$

La costumbre moderna de conservar y adoptar los hijos recién nacidos de los cautivos, demostrado judicialmente en Argentina ¿no es semejante a la conservación de posesiones del enemigo muerto? Una parte del enemigo derrotado, esta vez viva, es asimilada para fortalecer al vencedor, por así decir en su homenaje. También en los pueblos antiguos era común adoptar a los hijos cautivos del vencido.

\section{LA Muerte De LOS OTROS}

Según Canetti la pasión de sobrevivir a otros está en el corazón del poder. El temor que todos experimentamos ante la muerte, se alivia al ver que el muerto es otro y no uno. "El terror que un muerto yacente produce en el ánimo de quien lo mira es sustituido por una satisfacción: el observador no es el muerto. Hubiera podido serlo. Pero quien yace es el otro (...) tenemos de pronto la impresión de que la muerte, que nos estaba amenazando, ha sido desviada de nosotros mismos al difunto" 5 . Esta pasión por sobrevivir está exaltada en el poderoso. Según Canetti, esta pasión es la esencia del poder, en sus formas absolutas. "Pues la sensación de felicidad producida por el hecho concreto de sobrevivir es un placer intensivo. Una vez confesado y aprobado, exigirá ser repetido y crecerá rápidamente hasta convertirse en una pasión insaciable. Quien se halle poseído por ella, se apropiará de las formas de vida social de su entorno poniéndolas al servicio de esta pasión. Esta pasión es la del poder"6.

Esta familiaridad del poder con la muerte de los otros está expresado en una costumbre de las islas Fidji, citado por Canetti:

"el prestigio de esta valentía bélica era tan grande que existían cuatro nombres diferentes para designar a los héroes, según el número de enemigos muertos. En el grado más bajo de la escala se hallaba el koroi, el que ha matado a un solo hombre. Koli se llamaba el que mataba a diez personas; visa, el que liquidaba a veinte; y wangka, el que había matado a treinta. Los que superaban esta cifra recibían un nombre compuesto. Un célebre cabecilla se llamaba Koli-visa-wangka: había matado a $10+20+30$, es decir, a 60 seres humanos" 7 .

En Chile ¿cuántos Koli y wangka hay entre nosotros? ¿Son admirables o terribles? Es un hecho que el número de los muertos fortaleció un régimen que duró tantos años. Miles al morir perdieron su mana, el que fue traspasado a los vencedores -o verdugos- que así gobernaron muchos años, con la grandeza del poder, y el terror. Delirio vuelto realidad, por la extraña magia de la dictadura.

\footnotetext{
${ }^{4}$ Idem.

5 Idem.

${ }^{6}$ Idem.

7 Idem.
} 
La dignidad de la muerte está asociada íntimamente al poder que es capaz de engendrar. Quizá esto explique un hecho notable. El hecho de que en el ocaso del régimen autoritario, solo se hayan inventariado las muertes, como abusos del poder a los derechos humanos. Cierto, la muerte es lo más atroz, y merece ser investigada. Ahora bien, la muerte confiere cierta dignidad, deja en el aire la idea de una batalla -aunque sea fingida-, tiene la dignidad de la guerra, tan cara al poder. Sin embargo, debilitada la dictadura, hay una notable ceguera para otro de los grandes abusos del poder desde luego mucho más numerosos: la tortura y la prisión. ¿Cómo explicarse la cautela de los demócratas con el poder saliente, para no inventariar esa forma mitigada de muerte que es la tortura? Decir tres mil muertos, es todavía aparentemente glorioso para muchos. Decir trescientos mil torturados, o trescientos mil exiliados definitivamente no es prestigioso. Esas cuentas no se han sacado por muchos años. Solo recientemente se inventariaron el número de prisioneros y torturados en la Comisión Valech, gesto importante y sanador. Pero falta aún para concluir la descripción e inventario de la violencia del poder y por avanzar en la tarea de su superación.

Poner el acento en los muertos fue necesario ya que confronta al poder autoritario en un punto decisivo. Pero es necesario también confrontarlo con el número de personas que torturó o exilió. Inventariar la agresión máxima, la muerte, nos ayuda, pero también conocer de esos otros sufrimientos infligidos a los sobrevivientes, que son como muertes parciales e invisibles.

El dictador, el gran hombre, sufrió un gran empequeñecimiento al traspasar el poder el año 90 si bien retuvo una influencia considerable, que algunos consideraron decisiva, ejercida entre bambalinas. Su figura finalmente se redujo drásticamente con su detención en Londres. Eso fue en definitiva su muerte política. Desde entonces se convierte en un fantasma de sí mismo, en un simulacro, apuntalado por sus amigos y herederos. El invencible fue vencido, había perdido su mana. Parte de su mana ha sido traspasado a otros ¡a quién?, ¿a un juez?, ¿a una instancia judicial internacional por crearse? Quizá la democracia renuncia definitivamente a esta magia supersticiosa y cruel más propia del poder total.

El delirio del poder que encarnó entre nosotros la figura concreta de Pinochet se está desvaneciendo ante nuestros ojos. El delirio se esfuma, pero quedará guardado en las conciencias. Alguno soñará con resucitarlo.

\section{EL VERDUGO: HERMANO DEL TORTURADOR MODERNO}

\section{UN FUNCIONARIO OLVIDADO}

Encontramos la descripción de un viejo verdugo francés en Sociología del Verdugo ${ }^{8}$, de Roger Caillois. Comparemos su retrato con la figura del torturador moderno. ¿Cómo es el rostro de un hombre que realiza la tarea de matar por orden del Estado?

${ }^{8}$ CAILloIS, Roger. Sociología del Verdugo, en Instintos y Sociedad. Barcelona: Seix Barral, 1969. 
Anatole Deibler falleció el 2 de febrero de 1939 a los 76 años de muerte natural. Los diarios comentan la vida de este personaje que ofició de verdugo por muchos años e hizo rodar más de cuatrocientas cabezas de sus conciudadanos. Mientras vivía, el foco de atención pública fue el ejecutado, nunca el ejecutor. Con la muerte del verdugo, la curiosidad ciudadana se vuelve hacia él. Su muerte lo descubre, lo revela. En los diarios se evocan episodios de su vida.

Hay un contraste entre el carácter del verdugo y su oficio. Aunque la tarea espanta, el hombre es descrito como amable, temeroso, de preferencias espontáneas de tipo familiar. Pasea a su perrito, va al hipódromo, es rentista, jubilado, es un buen funcionario, buen padre de familia, ayuda a los pobres, le atribuyen un corazón sensible, cultiva flores, hace vasijas artísticas. En su vida personal se lo describe atormentado, más que aquellos que sufren sus rigores. El error de un farmacéutico provoca la muerte de su hijo de cinco años; su hija envejece sin encontrar marido, es un hombre melancólico. Desde su infancia había sido discriminado por los demás niños, debido al oficio de su padre, que él desconocía. Los compañeros lo molestan y un día le gritan que su padre es verdugo. Después de reponerse, él jugaría a guillotinar y asustar a sus compañeros. La maldición lo persiguió. Nadie le da trabajo, nadie consiente que su hija se case con el hijo del verdugo. Incluso el carpintero que construye guillotinas y cadalsos, rechaza a este pretendiente. La desgracia en el amor, lo lleva finalmente a aceptar suceder a su padre en el oficio. El cargo solía ser hereditario: Deibler fue hijo, nieto y bisnieto de verdugos. Quien desempeña este oficio tiene la prerrogativa de designar su sucesor. El último Deibler, al no tener descendiente varón, designa a su sobrino. Es como si este hombre fuera víctima de una maldición, el oficio familiar. Una cascada de frustraciones lo lleva a hacerse verdugo. Un hombre atormentado se convertirá en el ejecutor del Estado. Relatos más antiguos hablan de otros que tomaron este oficio por un amor desgraciado.

El verdugo Deibler es un funcionario especial, no es un empleado normal, sino que depende directamente del Ministerio de Justicia y a quien se le paga con fondos de un capítulo especial del presupuesto. También en Chile y América Latina la represión política fue realizada por funcionarios que el Estado no quería reconocer y mediante fondos reservados. Nos dice Caillois en 1939: "se quiere dar a entender que el Estado no le conoce. En todo caso en un punto especial está fuera de la ley: se le 'olvida' en los registros de conscripción" 9 . Los hijos de los verdugos están dispensados del servicio militar. Las instituciones oficiales se distancian de este personaje incómodo, no quieren nada con él.

\section{EL VERDUGO: EL DOBLE DEL REY}

Analiza Caillois el rasgo más impresionante de este personaje. El verdugo ocupa en la escala social un lugar simétrico, pero invertido al del Rey. El verdugo abajo y el soberano arriba, constituyen una pareja extrañamente emparentada precisamente en su oposición. Varios hechos revelan esta sorprendente asimilación entre ejecutor de justicia y el depositario del poder. Vimos el carácter hereditario que acompaña al oficio, asimismo rasgo de la

\footnotetext{
${ }^{9}$ Idem.
} 
realeza. También la prerrogativa - propia del soberano- de designar sucesor. Otra: la tradición de perdonar la vida del primer condenado a ser ejecutado, después de que el verdugo titular muere. El indulto que el rey concede por gracia, lo otorga el verdugo con su muerte. El nacimiento de un heredero al trono, solía originar esta gracia también.

Por su oficio, el verdugo ocupa un lugar despreciado y, simultáneamente con raros privilegios: "apreta el botón homicida en nombre del pueblo francés: solo él puede hacerlo" ${ }^{10}$. Se le llama "Monsieur de Paris" con aires de título de nobleza, como si fuera un obispo. La fría racionalidad es insuficiente para explicarnos todo esto. Incluso su ropa, elegante en extremo, "convierte al verdugo para los ojos, es una especie de doble siniestro del jefe de Estado"11. Recuerda Caillois otros datos curiosos. En algunos estados de Alemania, el verdugo, al llegar a un determinado número de víctimas, adquiría ciertos títulos de nobleza. "En Wurtenberg tenía derecho a hacerse llamar 'doctor"'12. En Francia gozaba de ciertos privilegios económicos: la Municipalidad le daba una ración de telas para vestirse, cobraba derechos sobre la verdura del mercado central; podía sacar cereales sin costo. Sustituía al rey en cierta obligación precisa: sentaba a su mesa a los Caballeros de San Luis empobrecidos. Una corte de pacotilla rodea al verdugo.

Hay así semejanzas entre soberano y verdugo. Uno, precisamente, por antagonismo o semejanza, evoca al otro. Uno manda al ejército; el otro está excluido de él. Ambos son intocables, estando rodeados de interdicciones frente al ciudadano común. Casarse para ambos es difícil. "El nacimiento aísla a ambos en su grandeza o en su ignominia"13.

\section{UN PERSONAJE DE LA FRONTERA SOCIAL}

El verdugo tiene fama de proximidad con la brujería, es algo así como un sacerdote al revés. En la tradición hay relatos de curaciones obradas por verdugos, hasta en el siglo XIX. El de Nims fue célebre. El arroyo, donde se lavó la sangre de uno de ellos, tiene propiedades curativas desde entonces. Accede a ingredientes extraídos de cadáveres que, según se dice, son útiles para ciertas enfermedades, el reumatismo, la epilepsia. Conserva el verdugo, por un tiempo, el derecho a vender los despojos de los supliciados, que la superstición convirtió en talismanes.

Es el último servidor de la ley, su lugar está cerca de la transgresión que combate, en una peligrosa y antigua vecindad. En la Edad Media, se confinaba su morada a los suburbios, cerca de criminales y prostitutas. Oficio ingrato y cercano "a la parte no asimilada del cuerpo social. Las más de las veces es un criminal perdonado. En otros tiempos, era el último instalado en la ciudad; en Suabia, el último concejal elegido; en Franconia, el último casado" ${ }^{14}$. Como se ve, fue una tarea con la cual se pagaba el derecho a ingresar a una categoría social, hasta ser reemplazado por el próximo recién llegado.

\footnotetext{
${ }^{10}$ Idem.

${ }^{11}$ Idem.

12 Idem.

13 Idem.

${ }^{14}$ Idem.
} 
En Francia, en el antiguo régimen ¿cuál era el procedimiento para nombrar al verdugo?: "se le arroja el documento bajo la mesa, adonde debe ir a recogerlo, arrastrándo$\mathrm{se}{ }^{15}$. Este ritual humillante muestra algo de su rol. La autoridad no debe tocar su mano. El verdugo es el hombre que mata en nombre de la ley.

"Deja al soberano la parte prestigiosa y se encarga de la parte infamante. La sangre que mancha sus manos no salpicará al tribunal que pronunció la sentencia: el ejecutor toma sobre sí todo el horror de la ejecución. Por el mismo hecho se encuentra asimilado a los criminales que sacrifica" 16 . Se ha dicho que "ese colmo viviente de abyección es, sin embargo, la condición y el sostén de toda grandeza, de todo poderío, de toda subordinación" 17 .

La majestad del soberano supone el oprobio que asume el verdugo. Soberano y verdugo, cara y sello del poder.

Volviendo a nuestra época ¿no vemos que perdura esta oscura relación entre la violencia y poder? Relación atenuada en democracia, pero ruidosa y evidente en dictadura. Ayer, el temor al brazo del rey servía a la cohesión social. Más recientemente, en dictadura la violencia del terror de Estado ha impuesto orden al cuerpo social. Antiguamente, el verdugo; recientemente, el agente sin rostro al servicio del poder. Aquí en vez de encapuchar al verdugo, se solía cubrir a las víctimas.

\section{EL REGICIDIO: ENCUENTRO DEL VERDUGO Y EL REY}

Además del recuerdo de amores entre miembros de la familia real y del verdugo, contado por los cuentos populares, hay un momento de contacto, que produce espanto al pueblo. Es la ejecución del rey, culminación de toda revolución. Es la victoria del desorden para fundar inmediatamente uno nuevo. Se rompe un cetro para construir otro. La sangre divina del soberano bautiza la soberanía naciente. Es un crimen sagrado que instaura lo nuevo.

Todo esto se observa en la Revolución Francesa. Se intenta en ella prestigiar el papel del verdugo: se prohíbe llamarlo así, para evitarle la infamia. Un decreto "da a los ejecutores de justicia el grado de oficiales en los ejércitos de la República. Un general hace grabar la guillotina en su sello"18. (Nuestros regímenes modernos han conservado esta manía de honrar a los verdugos y ocultar su condición). A la caída del rey corresponde la promoción del verdugo. El rey está preso. El discurso de Saint Just lo condena: Luis debe "reinar o morir (...) no se puede reinar inocentemente"19. Sabiduría que sigue cumpliéndose. La muerte del rey será la fundación misma de la República y constituirá para ella "un vínculo de espíritu público y de unidad”. ${ }^{20}$ La ejecución de Luis XVI "se ofrece como prenda y símbolo del advenimiento de un nuevo régimen" ${ }^{21}$.

\footnotetext{
15 Idem.

${ }^{16}$ Idem.

${ }^{17}$ Idem.

18 Idem.

19 Idem.

${ }^{20}$ Idem.

${ }^{21}$ Idem.
} 


\section{¿UN REGICIDIO MODERNO?}

¿No vivimos todo esto en el Chile del 73? Allí comprobamos en carne propia lo que es una revolución. Ella culmina o se inaugura con un crimen sagrado, una "ejecución que se ofrece como prenda y símbolo del advenimiento de un nuevo régimen" ${ }^{22}$. Un libro de interpretación histórica causó impacto en el público, lo que muestra el ansia de recuperar el pasado y pensarlo. Su autor, también sociólogo, escribe de modo que recuerda a Callois:

"El bombardeo de La Moneda por los aviones militares, con el Presidente y sus hombres adentro. El palacio ardiendo, arrasado por bombas lanzadas por feroces máquinas de guerra, mientras Allende estaba allí, entre medio de la metralla, el humo, los restos destruidos del Estado. Ese acto constituyó el asesinato del Presidente en funciones. El suicidio fue la formalización de una muerte ya ejecutada (...) Bombardear desde el aire el Palacio de Gobierno ya expresa una voluntad de tabla rasa, de crear un nuevo Estado sobre las ruinas del otro. Se realizó con ella la 'destrucción del Estado precedente'. Para culminar aquello, lo ideal era que el Presidente muriera. Su salvación física fue entregada al azar”23.

La muerte de un rey, la muerte de un presidente. ¿No generan ambos espanto? O, en algunos, alegría feroz. Se ejecuta a un rey: fragilidad del poder. Asalto al Palacio de Invierno de los Zares, bombardeo al palacio presidencial. Es el crimen sagrado de las revoluciones. Es el encuentro del verdugo y del rey. Uno es el alter ego del otro, el doble del otro: doble glorioso, doble siniestro. En la revolución triunfante, el poder se invierte y el verdugo mata al rey para inaugurar un nuevo orden. Pecado original y culpa del poder político, periódicamente renovado.

El verdugo, personaje con resonancias misteriosas y primitivas se resiste a un orden sistemático como quisiera la razón. "Así verdugo y soberano forman pareja. Aseguran de consuno la cohesión del cuerpo social, uno lleva el cetro y la corona (...) el otro lleva el peso de los pecados que arrastra necesariamente su oficio, por justo y moderado que sea" ${ }^{24}$. Es un personaje de leyenda, como el rey, y sagrado como él. Reina en él, el mito; y no lo explican la abstracción y la razón.

¿Cuántos de estos rasgos del verdugo europeo sobreviven transformados en nuestros modernos ejecutores de violencia? El poder totalitario en América Latina ha surgido generalmente de revoluciones de la milicia imponiendo su ley de hierro. La violencia del terrorismo de Estado no adopta formas jurídicas sino carece de tribunales, opera en el silencio, se oculta. Algunos rasgos del antiguo personaje del verdugo se repiten en estos remedos modernos que han operado en Chile y América Latina. Aquellos nombres que han sido conocidos y juzgados han ido creciendo. Se los ha presentado como gente normal, de vida familiar y buena conducta. ¿Cuáles serán las tragedias familiares en las que quizá se busque justificarlos, como al verdugo de París? Falta hacer la genealogía de

\footnotetext{
22 Idem.

23 Moulian, Tomás. Chile actual, Anatomía de un Mito. Santiago: LOM Ediciones, 1997.

${ }^{24}$ Caillois, Roger, loc. cit. (n. 8).
} 
nuestros verdugos. Nuestra época los llamó "agentes de inteligencia” para dignificar su sucio oficio, en una operación verbal semejante a la revolución francesa, que a sus verdugos quitó ese nombre para darles el de vengadores del pueblo. El Estado tuvo funcionarios que reconoce necesarios, pero los trató como si no fueran funcionarios. Al Estado le es incómodo reconocer su vínculo con ellos, se les pagó con fondos especiales de los que no quedaron registros. Son personajes temidos que asustan y fascinan.

Caillois escribió su trabajo sobre el verdugo en 1939, en una Europa preñada de violencia, que pronto estallaría por todas partes. Hacía un trabajo histórico, de un personaje a medias real, a medias fantasmal, que encarna la violencia en época de paz. Citamos a Caillois en un gesto de invocación. Hemos vivido tanta violencia en los años recientes, que quizá es difícil y prematuro hablar de ella. Miramos el presente dando un rodeo a través de la figura de un hombre, el verdugo Deibler fallecido hace sesenta años.

\section{4. ¿GUERRA SUCIA O JUSTICIA SUCIA?}

En Chile, quienes dieron muerte a opositores al régimen autoritario, se veían a sí mismos como soldados cumpliendo su tarea. Sugerimos mirar a esos hombres como verdugos, y no como soldados, como lo quería la versión oficial. Sabemos que estas violencias han sido calificadas como delitos, por recientes fallos judiciales. Sus autores han sido definidos entonces como delincuentes. Estos acontecimientos judiciales son notables. Sin embargo, ante miles de violencias, solo unas pocas han podido ser castigadas legalmente, y esto con enormes resistencias. Pero los partidarios del gobierno militar piensan que esas violencias no fueron delitos; ni sus autores, delincuentes. La violencia fue entonces ¿guerra "sucia” o lisa y llanamente crimen? La misma ley de amnistía reconoce que los hechos, que en adelante serán "olvidados", son delitos, son punibles. Solo los crímenes se ocultan o se busca olvidarlos. Las guerras -sobre todo las victoriosas- son en cambio, intencionalmente recordadas.

En el primer período del régimen militar funcionó una justicia revolucionaria, muchas veces secreta, que liquidó a quienes temía como rivales: una “justicia” de tiempos de guerra. Hubo opositores al régimen militar que posiblemente murieron efectivamente en enfrentamientos. Pero la gran mayoría murió en cautiverio: allí entonces actuaron verdugos. Los militares creían quizá hacer la guerra, para la que se habían formado. Pero los zarpazos escondían las manos de hombres de rostro oculto. En vez de guerra, hubo una cruel parodia de justicia: fue el simple y desnudo terror que suele seguir la consolidación de toda revolución.

\section{LA INDIGNIDAD DE MATAR}

Hegel en sus Escritos de Juventud señalaba hace casi dos siglos, a propósito de las ejecuciones capitales realizadas públicamente, la indefensión del condenado a muerte y la dureza del oficio del verdugo, tarea sin honor ${ }^{25}$. El condenado busca aturdirse, ¿no querrá también aturdirse el verdugo? El autor muestra la gran diferencia entre un hombre que

${ }^{25}$ Hegel, G.W.F. Escritos de Juventud. México: Fondo de Cultura Económica, 1984. 
realmente muere en batalla, y el hombre que en cambio muere ejecutado, indefenso. "El hombre que muere en la lucha contra otro puede despertar nuestra compasión, pero en su muerte no aparece ese momento mortificador que se presenta en la muerte del ajusticiado, puesto que el primero pudo ejercer su derecho natural de defender su vida. Cayó porque el otro ejercía el mismo derecho" ${ }^{26}$. La muerte en batalla conserva dignidad: pensemos en nuestros héroes. El ejecutado, en cambio, recibía una muerte innoble, inhumana, pues se le arrebata el derecho a defenderse, a luchar. Su indefensión es mortificación, tormento añadido, tortura que duplica la muerte.

Hegel describe cómo la ejecución pública hiere la sensibilidad de los espectadores. El pueblo puede llegar a sentir ira, solo contenida por el sentimiento de que la ley es sagrada. Solo la majestad de la ley es capaz de contener la indignación de ver matar a un hombre indefenso. En Chile la indignación era contenida, en unos, por el respeto al nuevo régimen; en otros, por el miedo.

¿Qué sentimientos surgen frente a la persona del ejecutor? Hegel habla de "aquella sensación general, que ha hecho que se imprima el sello de deshonestidad sobre el oficio de unos hombres capaces de matar a sangre fría y públicamente a un hombre indefenso, y que cumplen con su función cual instrumentos ciegos, parecidos a los animales salvajes a los cuales antes se arrojaba a los criminales" 27 . Matar a sangre fría incluso sirviendo a la justicia, es tarea poco digna de hombres. El verdugo reemplaza a las fieras del viejo circo romano. Un oficio que despierta desagrado y tiene un sello de deshonestidad.

En la antigua Grecia al parecer no era necesario el ejemplo de la ejecución pública: "Según entiendo, entre los griegos no hubo ajusticiamientos públicos. Sócrates, por lo menos, bebió la copa en la cárcel, y Orestes -en la pieza de Eurípides- debía también propinarse él mismo la forma de muerte que había elegido" ${ }^{28}$. Después de la condena, el condenado debía administrarse su propia muerte en cumplimiento de la sentencia. Esta antigua costumbre griega sugiere una relación entre suicidio y pena de muerte. Un suicidio, incluso de un desconocido, tiene algo que nos sobrecoge y nos hace sentir vagamente culpables. Esa muerte ha ocurrido como si el suicida hubiese obedecido una invisible sentencia que desconocíamos y nos la presenta sorpresivamente ya cumplida. Seguro algún dolor real colaboró con esa pena. Consumado el fin, es tarde ya para aplacar el rigor de un veredicto del que nos sentimos involuntariamente partícipes y cuya ejecución quizá hubiéramos querido suspender. Es ya tarde para la gracia. La autoaniquilación muestra con claridad lo atroz de toda muerte, sea ordenada judicialmente o no, sea la propia o la ajena.

Algunos familiares de un ejecutado político o desaparecido buscan años después la muerte voluntaria. En esos casos quizá se puede pensar que en cierto modo solo hubo libertad en la muerte primera y original: en la ejecución o el desaparecimiento. Ya sabemos que la desaparición de cuerpos significó muerte por tortura o ejecución sumaria, seguido por entierro clandestino y en muchos casos por desentierro y ocultamiento. Esas primeras muertes que infligió el poder a veces trajeron como consecuencia un eco, una duplicación: el suicidio del hijo o el familiar años después. La segunda muerte repitió y fue causada por

\footnotetext{
${ }^{26}$ Idem.

27 Idem.

28 Idem.
} 
la primera. El poder del terror así consiguió en un solo gesto dos muertes enlazadas, solo que desfasadas en el tiempo. Consecuencia de la tortura larga y cotidiana que el poder dejó instalada en la familia. Es la violencia que alimenta al poder.

En una dictadura moderna crecía cada año el número de suicidios. Se optó por no contabilizarlos, o al menos no dar las cifras al público. El poder totalitario carece de vergüenza y no es por pudor que oculta este número trágico. El poder más bien se siente humillado por cada suicidio, es una muerte que él no infligió. El suicida hace un gesto personal, que le arrebata su vida, al poder, en cierto modo vuelve al poder momentáneamente impotente. El suicida es un fugado aunque sea en la muerte y la dictadura le disgusta que se escapen a quienes quiere sometidos. Si un ciudadano se siente destruido en sus posibilidades vitales y sufre sintiéndose muerto en vida, eso complace al poder que se sabe victorioso. El escape de la víctima hacia la muerte disgusta al poder, pues envuelve una desobediencia. La vida no le importa al poder absoluto que solo se ama a sí mismo.

\section{EJECUCIÓN ¿PÚBLICA O SECRETA?}

En Chile, durante los años de dictadura, hubo cientos de muertes ejecutadas en secreto: Lonquén, Paine y tantas otras. En la práctica, esas muertes operaron durante largo tiempo como simulacros de justicia. Personas con poder suficiente dictaban sentencias que eran ejecutadas secretamente y no eran leídos sus fundamentos ante nadie. Si alguna muerte ocasional ocurría como solían decir "por excesos" -o desenfrenos- de inmediato se les aprobaba por omisión pues no se castigaba esa muerte quizá no autorizada. Más aún, muy luego se ascendía y condecoraba a los ejecutores.

La indignidad de esta tarea de exterminio era evidente hasta para los hechores. De ahí la necesidad de prestarle una dignidad que le faltaba. Donde no hubo en realidad batalla, frecuentemente se la inventó: los muertos fueron declarados caídos en enfrentamientos. Era preferible aparecer como soldados más bien que como verdugos. O se optaba por borrar todo rastro de esta poca honrosa tarea: desaparecido. Actualmente el aparato judicial declara aunque tardíamente que matar a un hombre incluso al enemigo político, es un crimen. Pero esta conclusión no es aceptada por todos, especialmente por quienes ejercieron el poder autoritario. ¿Cómo fue posible que la violencia que llegó a afectar a varios miles de personas y que hoy comienza a ser considerado un delito, pudo ser en su tiempo, tan extendida y aceptada?

El delito, la transgresión, la violación de la regla, se multiplicaron en dictadura. Lo excepcional se transformó en una nueva regla: estado de excepción. En un pueblo con un fuerte sentimiento interior de la ley como en el antiguo caso griego no hacían falta ejecuciones públicas. Pero cuando la ley es exterior al sujeto, se hace necesaria la coerción y eventualmente la agresión y la muerte. Una justicia salvaje fue llamada a disciplinar cuerpos y espíritus. Las revoluciones necesitan del terror, el que modernamente debe ser ejercido en forma semioculta. Una vez que la disciplina ha vuelto a ser internalizada, la coerción puede ser nuevamente atenuada. Cuando la nueva legalidad ha sido ya adoptada, de pronto el verdugo parece volverse innecesario, odioso, transformándose en un personaje arcaico. Nos sorprende incluso que haya podido existir y llegamos a dudar de ello. Sin 
embargo, cuando las nuevas reglas aun frágiles y cuestionadas son amenazadas, surge el temor de su resurrección. En tiempos normales, la facultad de disciplinar imponiendo la muerte la tiene exclusivamente la justicia. En el régimen militar, la justicia de los jueces se desvaneció, existía un estado "de excepción” e imperó el poder político sin contrapeso. O mejor, el poder confiscó en los hechos la tarea judicial, aunque formalmente respetara la institución que normalmente la ejercía.

Durante muchos años operó una justicia draconiana ejercida por un aparato irregular, del cual se han conocido gradualmente algunos fragmentos. Muchos de los que allí trabajaron creyendo ser soldados, solo fueron ajusticiadores. En vez de delincuentes, eliminaron enemigos políticos. En nuestras características como país, lamentablemente, debemos incluir nuestra capacidad para generar verdugos y nuestra increíble tolerancia con ellos.

Era costumbre en nuestro país que la pena de muerte judicial, fuera ejecutada por un pelotón de fusilamiento. Se buscaba diluir la ingrata tarea en el grupo. Además, se incluyó un artilugio para que cada fusilero pudiera guardar la esperanza de no haber sido él, el verdugo. Uno de ellos recibía al azar balas de fogueo. Fueron los demás y no yo, podía pensar. Se protegía al ejecutor, aliviándolo del peso emocional de la certeza de haber matado.

Esta costumbre ¿acaso se amplió en forma gigantesca en la época de represión política? Ciertamente se intentó diluir la responsabilidad de los ejecutores a través del en el secreto y el anonimato. ¿Habrán sido algunos ejecutores señalados al azar? En todo caso se los protegió. Al parecer nadie mató, de creerse las declaraciones oficiales. Hasta el final los acusados niegan. Siempre fueron otros. Se responsabiliza al fin a una supuesta y abstracta necesidad del Estado.

\section{LA VIOLENCIA: UN FRACASO}

Está claro que el asesinato político es un crimen. Gobernar por el temor es un crimen, pese a que se trata de una práctica histórica frecuente. Pero incluso la violencia judicial de tiempos normales, como veíamos, conserva algo de sucio, de deshonesto. Nos surgió la idea de comparar la violencia política moderna con la violencia judicial, según las palabras de Hegel. El propósito no es legitimar el temor sembrado por el Estado, disimulándolo como si fuera una práctica judicial o semilegal ¡no! Al contrario, el propósito es mostrar algunas marcas inhumanas que tiene la violencia del hombre sobre el hombre incluso allí donde es legal y está socialmente permitida. No queremos entonces, decir que la violencia represiva fue una pena o una cirugía necesaria, como ha dicho precisamente el poder buscando justificarse. Sino mostrar cómo hasta la violencia que sería la única justa, la violencia judicial, la pena impuesta por el juez y su brazo arcaico, incluso esa violencia tiene algo de atroz e inhumano. Si la muerte infligida por un hombre contra otro por sentencia legal es horrible, con mucha mayor razón lo será cuando esa muerte no tiene fundamento legal alguno, como es el terrorismo ordenado por el Estado revolucionario.

Los responsables intentan negar su responsabilidad. Reconocen implícitamente lo atroz de sus actos, al intentar escamotearlos. Su mentira delata su mala conciencia pues un acto honroso o inevitable no se niega ni se oculta. No ocurrieron, decían en su tiempo, son fábulas para calumniar al gobierno. Son las propias víctimas las que se diezmaron entre ellos, 
decían. Finalmente como a regañadientes, se reconoce que existieron algunas violencias, pero se les denominó excesos, casos aislados. Se intentó cubrir todo con un montón de silencio. Hay cosas sobre las que simplemente no se puede hablar. En Alemania y Francia han demorado dos o tres generaciones en poder hablar públicamente de ciertos temas referidos a la violencia. ¿Cuánto demoraremos aquí en atrevernos a hablar a fondo?

En épocas pasadas la pareja opuesta del soberano y el verdugo, era considerada el sostén de la cohesión social. Pues bien, llama la atención la semejanza de esos dos personajes con el dictador moderno y su policía secreta. Antaño el poder del Soberano dependía de la opaca figura del verdugo. El dictador, como antes el rey, encarna a la nación en su persona, con un aura de honor y prestigio. Por el contrario, el verdugo de antes, como el agente represivo moderno, asumen el oprobio y la sangre.

\section{RETROCESO DEL DERECHO EN DICTADURA}

La historia del derecho contada por Foucault en La Verdad y las Formas Jurídicas, ilumina acontecimientos recientes en $\mathrm{Chile}^{29}$. En un gobierno autoritario hay una vuelta atrás retrocediéndose a formas antiguas y ya superadas del derecho. Con la transición a la democracia se intenta recuperar nuevamente formas modernas de administración de justicia.

\section{EL PODER DE LA VERDAD EN GRECIA}

En Grecia hubo una evolución del derecho en que al final el pueblo griego alcanzó la capacidad de controlar a quienes lo gobernaban, lo que se muestra en la obra Edipo Rey. En ella, Edipo es desenmascarado gradualmente como el asesino de su padre. Una investigación minuciosa va construyendo la verdad diseminada inicialmente en variados personajes, unos humildes (el pastor, el esclavo), otros poderosos (el adivino Tiresias). Cada uno posee un fragmento de saber que una vez unidos dibujan entre todos la verdad por completo. Quien vio es un testigo. Al final y esto es lo notable, sucede que la sola verdad es capaz de vencer al poderoso, quien recibe su castigo. Nació así el derecho de oponer una verdad sin poder al comienzo, a un poder sin verdad. En Grecia se elaboran las formas racionales de la prueba, del descubrimiento jurídico de la verdad. Esta forma de la investigación servirá de matriz para otros saberes, filosóficos y empíricos, característicos del pensamiento griego.

\section{LA FuerZa EN EL DERECHO GERMÁNiCO y FEUdAL}

En la Edad Media compiten varias formas del derecho. En el Derecho Germánico una ofensa es castigada por medio de una venganza sometida a reglas y ritualizada. La víctima o uno de sus parientes acusa al ofensor y la acción penal es "una especie de duelo u oposición entre individuos, familias o grupos" 30 . El derecho es una forma "reglamentada

\footnotetext{
${ }^{29}$ Foucault, M. La Verdad y las formas jurídicas. México: Gedisa, 1984.

${ }^{30} \mathrm{Idem}$.
} 
de conducir la guerra entre individuos y de encadenar los actos de venganza" 31 . Hay solo dos partes: el ofensor y la víctima que reclama. No hay una tercera instancia que controle la contienda, no existe un juez. Es la acusación de la víctima la que da inicio al proceso.

El ofensor puede escapar a la venganza consiguiendo un acuerdo, generalmente un rescate en dinero. Puede entonces, interrumpirse esta guerra ritualizada. En esta lucha puede producirse un compromiso: se trata de "una prueba de fuerza que puede terminar en transacción económica” 32 . No hay investigación, no hay aquí búsqueda de la verdad o la mentira. Estas son diferencias sustantivas con el derecho moderno y con el griego.

Luego en el Derecho Feudal se recoge la esencia del derecho germánico. En este derecho feudal tampoco hay investigación de la verdad. Es un sistema de prueba, en el sentido de lucha y desafío. La resolución se busca a través pruebas aceptadas por ambas partes que sirven de reglas de lucha. No se prueba la verdad sino la fuerza y la importancia de quien habla. Un acusado en Borgoña en el siglo XI presenta doce testigos que juran que él no ha cometido asesinato alguno. Se muestra así solidaridad social, peso, influencia, "la importancia del grupo al que pertenecía y de las personas dispuestas a apoyarlo en una batalla o conflicto" 33 , no importando aquí la verdad. Residuos de esta práctica subsisten actualmente en la certificación de la buena conducta anterior afirmada por personas influyentes, o la exhibición de pertenencia a grupos de poder para impresionar al tribunal, o en la impresión de que tal gran personaje parece estar por sobre cualquier acusación de una conducta innoble.

Había pruebas verbales: ciertas fórmulas debían ser pronunciadas correctamente por el acusado o un sustituto que lo representa. Si se equivocaba, perdía el proceso. Quien debía repetir la fórmula se convertiría mucho después en la figura del abogado. Había pruebas corporales, como ser arrojado al agua amarrado. Caminar sobre brasas ardientes: si dos días después aún tenía cicatrices, perdía el proceso. En estos casos, la prueba es un torneo para establecer quién es el más fuerte de acuerdo a ciertas reglas que el público presente controlaba. El vencedor ganaba el proceso, no siendo necesaria la verdad. La prueba judicial solo ritualiza la lucha. El más fuerte precisamente, por serlo, tiene razón. En expresión de Foucault la prueba es un dispositivo "que permite el pasaje de la fuerza al derecho" 34 .

¿En la reciente dictadura no vivimos acaso en una parodia de este antiguo derecho feudal? En ella la fuerza fundó el derecho en la práctica y las leyes escritas quedaron solo como palabras, una retórica vacía -como lo sabía todo el mundo- cuando el pellejo estaba en juego. En las dictaduras latinoamericanas se enfrentaban el poder y los pequeños grupos rebeldes, que buscaban debilitarlo o derrocarlo. No existía una instancia tercera, estaba ausente un juez o autoridad que controlara la corrección de la lucha. La lucha consagraba al vencedor, quien parecía tener finalmente la razón e imponía la ley. Se pasa directamente de la fuerza al derecho. Estos rasgos guardan semejanza con el derecho feudal, por la primacía de la fuerza, en vez de la verdad. Debe reconocerse, en rigor, que en el derecho feudal había reglas aceptadas por las partes y un público que regulaba lo que

\footnotetext{
31 Idem.

32 Idem.

33 Idem.

${ }^{34}$ Idem.
} 
sucedía. En dictadura, entonces, se retrocede a un derecho, si puede llamarse así, aún más arcaico, primitivo y cruel.

De ahí los miles de recursos de amparo inútiles. El derecho no se generaba en los tribunales, que se convirtieron temporalmente a este respecto en edificios inertes, en virtuales museos de justicia. La justicia de ciega se volvió muda e impotente, salvo honrosas excepciones de jueces notables que en cualquier caso no podían revertir la situación general. La instancia judicial no amparaba sino que incluso percibía las demandas de los familiares de las víctimas como argucias, como escaramuzas en la lucha.

Carpentier en la novela El Recurso del Método, describe la lucha de dos personajes: el dictador y el líder revolucionario. La pugna atraviesa la nación, un país sudamericano. En un capítulo los hace conversar: se encuentran así el Primer Magistrado y el Estudiante. Se temen, y se desprecian, en cierto modo se respetan, quizás en toda dictadura solo hay dos personajes realmente libres, pues ambos son la fuente potencial de un derecho, solo que opuestos: el dictador y el revolucionario. Uno gobierna; al otro le espera probablemente la tragedia. Los demás somos unos sometidos, unos gobernados, en palabras de Foucault.

\section{DESAPARICIÓN DE LOS JUECES}

Solo hubo, en esos años, rarísimos casos de amparo concedidos. En uno de ellos, el 31 de enero de 1977, una corte "declara que el Señor Ministro del Interior, a fin de restablecer el imperio del derecho y asegurar la debida protección del amparado, deberá disponer su inmediata libertad"35. Citamos aquí a Patricia Verdugo en "Tiempo de Días Claros, los Desaparecidos”. Era un detenido que se fugó en pleno centro y habría intentado suicidarse arrojándose a las ruedas de un bus, para escapar de la tortura. Solo quedó herido, siendo apresado nuevamente ante decenas de testigos, incluso de Carabineros. Al ser aprehendido, gritó su nombre y señas de su familia. Los jueces esta única vez, otorgaron amparo. Obviamente fueron desobedecidos: la autoridad negó la detención, a pesar de que se conocían los nombres de los captores y el vehículo oficial utilizado. Un oficio de la Presidencia de la República se atrevió a sugerir que la desaparición pudiera ser responsabilidad de las propias víctimas: "preocupa al infrascrito que pudiera esta detención arbitraria haber sido premeditadamente efectuada por elementos subversivos" 36 . Luego el Poder Judicial decretó el fin de la causa "por no estar acreditados los hechos" ${ }^{37}$ en contra del amparo otorgado dos años antes.

El padre de este desaparecido, quien es abogado, expresaba:

"Recuerdo cuando, en los tres años de gobierno de la Unidad Popular, los jueces se constituían en las cárceles hasta en día Domingo para tramitar recursos de amparo a favor de detenidos. Y que distinto fue después, en circunstancias, que su obligación es actuar siempre con la misma diligencia, cuando en las cárceles están sus amigos y cuando están los que no tienen el "privilegio" de contarse entre sus amistades. Yo

${ }^{35}$ Verdugo, P. Tiempo de días claros, los desaparecidos. Santiago: Ediciones CESOC, 1990.

36 Idem.

37 Idem. 
me pregunto ¿cuántos chilenos hoy estarían vivos, a cuántos habrían salvado la vida si hubieran acogido los recursos de amparo a tiempo?"38.

A instancias de la Iglesia Católica, que les proporcionó un abogado se llevó a los tribunales el caso de 41 detenidos desaparecidos en Paine, llegando finalmente el día del alegato: "Fuimos todas las mujeres, madres, esposas y hermanos a la Corte Suprema cuando él hizo su alegato por nuestros hombres. Recuerdo que él llegó a llorar de emoción al contar lo que había pasado. Y ahí al frente, sentados en su estrado, estaban los jueces que no hicieron un gesto, no dijeron una palabra, no se inmutaron". Y agrega una madre del grupo: "Sentí tanta rabia, sentí por ellos un odio tan grande. ¡Que Dios me perdone, pero tenía ganas de matarlos! Tenía ganas que les pasara con sus hijos, para que entendieran lo que me pasaba a mí" 39 . Una nuera dice: "La justicia no sirve para nada, no existió para nosotros. Fuimos ignorados y rechazados. Los jueces no hicieron nada para buscar a nuestros maridos, dejaron que desaparecieran. Y después el gobierno del general castigó al abogado relegándolo a un pueblito del Norte" ${ }^{40}$ Esas mujeres en la Corte no ven jueces, sino figuras impotentes o cómplices frente al poder autoritario, estatuas de sal.

Un abogado afirma: "Cerca de ocho mil personas estuvieron desaparecidos por semanas y por meses provocando el temor de sus familias y amigos. Finalmente, unos mil jamás volvieron a aparecer" ${ }^{41}$. Otro abogado se refiere a los organismos de seguridad: "Ahí se toma la decisión de quien muere y quién sobrevive, salvo casos de quienes no resisten la tortura, excepciones que confirman la regla" 42 .

En 1982, un juez investigó la desaparición de diez personas dictando finalmente encargaturas de reo contra 40 personas, incluyendo altos jefes militares. Pocos días después, los tribunales superiores ordenan al juez dar por cerrado el caso en virtud del decreto ley de amnistía. El juez valientemente rechazó la tesis de sus superiores: "la orden de emitir sobreseimiento por amnistía es evidentemente contraria a Derecho, por inoportuna” 43 . Más aún, este juez señala que puede estarse incurriendo en un delito de prevaricación al sobreseer a los acusados. Vemos que en esta resolución, un juez excepcional enfrenta a los demás con la posibilidad de estar ¡los jueces mismos! cometiendo un delito. Resultado: la Corte Suprema castigó a este juez con dos meses de suspensión de su trabajo y sanciones económicas.

El Poder Judicial no tuvo voz propia sometiéndose completamente al poder autoritario, autoanulándose en su función de dar justicia. La figura del juez imparcial y con autoridad, desapareció. Ante jueces inmóviles, petrificados se desenvolvía la lucha entre un Poder Ejecutivo omnipotente que perseguía y diezmaba a los opositores políticos. Dos fuerzas de magnitud completamente desigual, en pugna. Nadie cumplía el rol de tercero, nadie ponía reglas a esta lucha. Una primera forma de control vino tardíamente, a través de la opinión pública internacional y los gobiernos extranjeros.

38 Idem.
${ }^{39}$ Idem.
${ }^{40}$ Idem.
${ }^{41}$ Idem.
${ }^{42}$ Idem.
${ }^{43}$ Idem. 


\section{¿TRIBUnales O BUZONES?}

Durante los tres años de Gobierno de la Unidad Popular, los sectores conservadores que se sentían amenazados defendían a los tribunales y recurrían a ellos. "Son los tribunales el único amparo de los ciudadanos perseguidos o atropellados en sus derechos" ${ }^{44}$, decía El Mercurio en un editorial del 26 de junio de 1973, y continuaba: "La destrucción del prestigio moral y de la autoridad efectiva de los tribunales importa dejar indefensos a los particulares frente a los grupos que aspiran a la totalidad del poder en el país" ${ }^{45}$. La Corte Suprema fue en esos tres años muy celosa de sus atribuciones y fustigó al gobierno de la Unidad Popular cuando se sentía atropellada. Así lo reconoce el propio Ministro de Justicia del Gobierno Militar, después del derrocamiento de la Unidad Popular: "Los casi tres años que precedieron al 11 de septiembre del 73 están empapados de la presencia de la Corte Suprema, de su ejemplo que hizo escuela en otras Cortes (...)"46. Lamentablemente después, la Corte perdió su presencia: desapareció. Los desaparecidos son el reflejo de una desaparición de la justicia y los jueces.

Los tribunales superiores renuncian a conceder amparo y a supervisar a los Consejos de Guerra de los primeros años. Renuncian a dirigirse por escrito a los organismos de seguridad, obedeciendo a la simple petición de un ministro de gobierno. Un jurista reclama: "hay que investigarlo todo bajo la premisa de que los agentes de la DINA no intervinieron, hay que olvidarse de ellos, en verdad no existen judicialmente" 47 en circunstancias que ellos fueron los protagonistas en los hechos criminales.

Aún más, el presidente de la Corte Suprema afirma el año 75 que el gobierno militar no los presiona: "los tribunales han continuado actuando con la independencia que les confiere la ley (...) ajenos a toda intromisión del gobierno" ${ }^{48}$. Y en el mismo discurso el juez se alinea con el gobierno autoritario. Critica a familiares que han presentado recursos de amparo, "estos recurrentes (...) han optado por el recurso de amparo a fin de dar más publicidad al asunto, no obstante la seguridad de su improcedencia" ${ }^{49}$. Incluso se queja de que las Cortes "han sido abrumadas en su trabajo con los numerosísimos recursos de amparo que se han interpuesto" 50 . Esto ha quitado a los tribunales "la oportunidad para preocuparse de asuntos urgentes”. ¡El juez se está burlando de las víctimas! Peor aún, la máxima autoridad de los jueces habla en ese mismo discurso como si formara parte del gobierno autoritario: "En cuanto a las torturas y atrocidades de igual naturaleza, puedo afirmar que aquí no existen paredones ni cortinas de hierro y cualquier afirmación en contrario se debe a una prensa proselitista de ideas que no pudieron ni podrán prosperar en nuestra patria" 51 . Es la alianza del Poder Judicial con el gobierno, sellada simbólicamente al imponer el presidente de la Corte Suprema la banda presidencial al general

\footnotetext{
${ }^{44}$ En: Revista Mensaje, Ed. No 250, junio, 1976.

45 Idem.

46 Idem.

${ }^{47}$ QueZada, Alejandro. La lección de la DINA, en: Revista Mensaje Vol. XXVII, Ed. № 270, Chile, julio 1978.

48 Idem.

${ }^{49}$ Idem.

${ }^{50}$ Idem.

${ }^{51}$ Idem.
} 
Pinochet ${ }^{52}$. En la práctica las Cortes solo sirvieron para recibir recursos, los que funcionaron solo como papeles: las cortes fueron reducidos al rol de buzones inertes. Magia perversa del poder que convirtió a los jueces en inexistentes, en muertos vivos.

Años después los jueces vuelven a la vida, investigando tardíamente, pero investigando al fin.

\section{UN REGICIDIO FRUSTRADO}

En plena dictadura se atentó contra la vida del jefe de Estado autoritario: intento de regicidio. Los responsables fueron apresados y torturados. Años después, muchos se fugarían. Es significativo que varios de los participantes en ese acto de violencia rebelde fueron reclutados precisamente entre anteriores víctimas del poder autoritario. Aquellos que fueron víctimas en los años 70, se transformaron en victimarios en los años 80 . Probablemente los que preparaban ese atentado sentían que, además de una tarea política, se cobraban una suerte de venganza, en una especie de justicia primitiva. A la violencia estatal sufrida ayer en carne propia, oponían luego la violencia revolucionaria, terrorista.

Todo esto recuerda el papel de la venganza en la justicia antigua, en el derecho germánico que hoy parece bárbaro en una sensibilidad moderna. Un clan que se considera víctima, se venga cobrando víctimas en el bando contrario. En este clima de bandos en pugna está dramáticamente ausente un tercero imparcial. Falta un juez, un estado neutral que confisque el litigio y lo administre, imponiéndole reglas judiciales, humanas. En la dictadura, el juez desaparece en beneficio del poder político. El Estado autoritario se considera uno y el mismo con la ley. Si alguna ley interfiere al dictador, simplemente dicta una nueva. O impone un estado de excepción, que le permite actuar sin restricciones.

Cuando no existe un tercero, un juez, hay condiciones propicias para el surgimiento de la venganza, como forma primitiva de justicia. En el caso del atentado al jefe de Estado, él salvó la vida, pero murieron cinco escoltas. A las pocas horas, operó la venganza, esa arcaica justicia: fueron asesinados un número similar de conocidos opositores al régimen. No importó que fueran periodistas o profesionales en vez de combatientes, el poder los consideró simbólicamente emparentados con los terroristas. Un periodista es visto como si fuera un soldado en dictadura. Por eso muchos oficios se volvieron peligrosos. Era la lucha entre clanes, ojo por ojo.

Pareciera que el progreso histórico trae nuevas costumbres que se van sobreponiendo a las antiguas como en estratos sobrepuestos. Lo nuevo recubre lo antiguo dominando viejas estructuras, que van quedando como edificios sumergidos. Al romperse las estructuras más nuevas, al faltar o volverse inútiles en la práctica, las fuerzas sociales encuentran los viejos cauces aparentemente olvidados y por allí corren, emergiendo viejas instituciones que creíamos superadas.

\footnotetext{
52 Méndez Fetter, P. Crisis de Confianza en la Justicia, en: Revista Mensaje Vol. XXVIII, Ed. N²84, Chile, noviembre 1979. Quien cita el discurso de inauguración del año judicial de 1975, pronunciado por el presidente de la Corte Suprema, 1978.
} 


\section{El Derecho a Fines de la EdAd Media}

El derecho feudal va desapareciendo en los siglos XII y XIII y surgen nuevas formas de justicia. En un nuevo derecho los oponentes deben someterse a un poder exterior a ellos y al cual ambas partes en litigio se someten. Surge una noción crucial: el delito lesiona no solo al afectado sino a la ley misma, a la sociedad. Aparece un personaje: el procurador, representante del señor o del rey, que protege la ley infringida y del lado de la víctima, acusa al ofensor.

Se desecha la forma de la prueba antigua adoptándose un procedimiento hasta entonces extrajudicial, la investigación. El poder reúne a los notables, en una zona, les pregunta la verdad, y pide que den una solución. Este procedimiento que había sido antes desarrollado en la administración es adoptado por el derecho. Había sido utilizado especialmente por la Iglesia con objetivos religiosos y económicos.

La investigación judicial en adelante averigua qué fue hecho y por quién. La confesión del culpable puede suspender la investigación acortándola. La investigación viene a ocupar el lugar que antes ocupaba el delito flagrante. Antiguamente, el delincuente sorprendido en acción, in fraganti, era llevado directamente a la justicia por el pueblo. Pues bien, la investigación lo que intenta hacer posible es reconstituir el crimen tal como ocurrió, aunque esta vez por medios indirectos. En la investigación el delito es reconstruido, como si volviera a ocurrir en el presente. Notable descubrimiento y pretensión: conocer como presente un hecho pasado. Idealmente, en la investigación exitosa se busca recomponer el delito pasado y ofrecerlo a la mirada, como si lo estuviésemos presenciando. Este sistema racional de investigación y prueba, aceptado hoy día para juzgar, nos hace sentir que los procedimientos anteriores son, por contraste, bárbaros, arcaicos, irracionales.

\section{RETORnO DEL DERECHO MOdERnO: EL CASO LETELIER}

La opinión pública contempló por televisión los alegatos de un caso de violación de derechos humanos, el caso Letelier. Asistimos allí a una doble contienda. La pugna entre las partes: los familiares de las víctimas y los acusados. Pero había otra contienda más profunda, más dura que se libraba en los gestos, los silencios, en el público, en el edificio mismo, en las calles, en el país entero mirando la transmisión. Esta segunda lucha, que no apareció en los alegatos se libraba entre un derecho moderno y un derecho antiguo. Entre un derecho nuevo donde prima la verdad, contra el derecho viejo de la fuerza. Entre un derecho moderno donde existe un juez, un tercero, ante el cual se someten las dos partes en pugna. Y por otro lado, un derecho antiguo, primitivo, brutal para nuestra sensibilidad, pero que nos rigió durante largos años: un derecho en que no había sino dos partes, la víctima y el ofensor, y en el que de antemano tenía la razón el más fuerte. En el derecho germánico y feudal tenía la razón el vencedor. Es la ley de la guerra, y es el derecho que ha regido la humanidad durante siglos. Es un derecho cruel que resucita de tiempo en tiempo. El caso Letelier fue una lucha entre estas dos figuras del derecho: el derecho de la fuerza versus el derecho de la verdad.

Quizá el caso Letelier es un caso bisagra que pertenece a ambos tipos de derecho. Pues en el derecho germánico se podía suspender el duelo entre las partes con una transacción, una negociación. Quizá este caso sea el último de un derecho feudal y al mismo tiempo el primero del derecho moderno que retorna. Pues, cosa notable, este juicio fue 
posible porque una nación extranjera lo permitió. De otro modo habría sido olvidado: amnistiado. Fue posible que se constituyera un juez, es decir, un tercero entre las partes, porque otro país suficientemente poderoso hizo oír su voz. Paradoja del derecho que nace con este juicio. ¿Hasta qué punto nos es impuesto -u otorgado- por otro poder que nos hace avanzar un paso adelante en el derecho? Fragilidad de una justicia que se hizo posible entre nosotros, por la presión de un tercero de fuera.

Este derecho de inquisitio es el que se desarrolla hasta la modernidad y que se pierde en los gobiernos autoritarios. ¿Cuál es la lucha que presenciamos en el caso Letelier? El retorno al procedimiento de un juez que investiga y reconoce una verdad por indicios, de manera indirecta. Los contendores, los familiares de la víctima y los acusados, se enfrentan delante de una instancia que representa al Estado y a la comunidad. Se reconstruye lo sucedido, se recompone entre muchos testigos la figura de un crimen y se castiga a los responsables. Una verdad inicialmente sin poder, consigue finalmente castigar a unos poderosos sin verdad. Es una nueva figura del Derecho, que quiere volver a afianzarse nuevamente. ¿Por cuánto tiempo?

\section{DE LA VIOLENCIA A LA PALABRA}

\section{DE LA CRIATURA AL CIUDADANO}

La psicoanalista francesa Francoise Dolto sugiere que el ser humano tiene dos nacimientos, a diferencia de los animales. El primero es el parto físico, el nacimiento del "mamífero" podría decirse. En este trance pasamos desde un estado más elemental in utero próximo a lo vegetativo a un estado animal. En el parto hay una pérdida y un duelo: en cierto modo muere el feto el cual era capaz de una comunicación inmediata y privilegiada con la madre, sin palabras. Se nace a lo desconocido. Solo podemos tener una pálida idea de nuestra experiencia de vida fetal. El niño al llenar por primera vez sus pulmones y gritar corre realmente un riesgo de muerte. Al perder el medio líquido que antes lo rodeaba el niño pierde el sonido de su propio corazón, que siempre lo acompañó. Más aún, el niño pierde esa intimidad de ritmos que lo conectaba con su madre, pierde "el ritmo del corazón de la madre que jugaba con el balanceo rápido del corazón fetal. Ya no oye dos ritmos que se buscaban, que se casaban" ${ }^{33}$. Al nacer, muere efectivamente una parte del nuevo ser: la placenta. Desde ahora el alimento en vez de venir por la sangre empezará a llegar por la boca. Son transformaciones impresionantes que nos cuesta concebir. Luego la boca servirá para gritar y después aprenderá a hablar. En adelante, el ambiente proporciona el alimento y el lenguaje. Las húmedas envolturas fetales serán reemplazadas después del parto por la invisible envoltura familiar.

Este primer nacimiento será seguido por otro más adelante, que se prepara en la infancia y culmina en la juventud, en un proceso gradual. "El segundo nacimiento es el paso del estado de dependencia animal a la libertad humana del sí y del no, un nacimiento

\footnotetext{
53 Dolto, F. La causa de los niños. Barcelona: Ed. Paidós, 1990.
} 
al espíritu, a la conciencia de la vida simbólica"54. En algún momento el niño que crece podrá decir no a los padres, será capaz de abandonarlos como fuente de apoyo y afirmarse en otros, en una vida fuera de casa. Dejará de ser una cría humana, habrá crecido, y será parte de la sociedad humana como uno entre otros como él. Habrá alcanzado la madurez.

Este segundo nacimiento equivale a la pérdida de la dependencia infantil y al paso del joven al mundo exterior a la familia. En un lento proceso el joven ingresa a la cultura, al trabajo, a la ciudad. Este es el segundo parto, en que nace un ciudadano. Pues bien, este mundo público exterior a la familia es lo que queda dañado en una dictadura. Una dictadura no quiere ciudadanos sino individuos dóciles, infantilizados. Será necesario más tarde recuperar un espacio público de participación, de encuentro con los otros y de confrontación no amenazante, de libertad y conversación, de democracia.

\section{LA PALABRA EN LA INFANCIA}

El psicoanálisis descubre la importancia de la palabra que el adulto dirige al niño, y el daño que le produce con un golpe. Pues si hay algo que obstaculiza la progresiva expansión del ser humano en desarrollo es la agresión y el golpe del adulto. "Si un adulto agrede físicamente a un niño, es porque a su respecto no tiene palabra" 55 Según Dolto, si un adulto golpea a un niño es que en cierta forma "no lo considera humano". Por medio de la violencia el adulto expulsa al niño de la comunidad humana y lo trata como a un objeto, como a un animal, como "nos servimos de una planta para cortarla, para que luzca en el jardin, la planta teme a ese jardinero" "56. El padre que golpea al niño ha renunciado a la palabra. El golpe arroja al niño fuera de la comunidad humana ya que esta se distingue precisamente por su capacidad de hablar. Ahora bien, si en cambio, el adulto enojado puede hablar de sus sentimientos al niño, su actitud dialogante le expresa su aceptación como hombre: lo está formando y concediendo un derecho. Dos que hablan ya son comunidad: la humanidad ha quedado a salvo. El problema puede ser llevado a las palabras: esta es la maravilla de ser hombres. Hablar del conflicto; hablarle al otro también del dolor o la rabia que me hizo sentir. El otro, niño o adulto, podrá escucharme y hacerse cargo de lo que ha hecho. Yo me hago cargo de lo que he sentido y lo digo. Milagro del lenguaje, es el pacto de las palabras, podemos encontrarnos en ellas, aunque sea en el conflicto, el que puede ser asumido en lo humano. Todo esta hermosa trama de comunidad se pierde con un golpe, con la agresión. Al ser golpeado el niño es educado y formado en lo no humano, en lo inhumano. Algunos de esos niños posiblemente obedecerán a ese adulto agresivo, pero quizá aprendan también a tratar a otros en forma no humana, a tratarlos como objetos, a mal-tratar.

¿Cuál es la solución frente al otro cuando es diferente y me frustra? ¿Y qué hacer frente al niño que actúa perturbando al adulto, y frente al enfermo, al viejo? Responde Dolto: "en el momento en que un individuo entre en pérdida, el grupo tiene la responsabilidad de ayudarlo a comprender, a reasumirse él mismo a su manera, y no por la fuerza,

\footnotetext{
${ }^{54}$ Idem.

55 Idem.

56 Idem.
} 
como se quiere que se asuma. Cambiar al hombre. ¿En qué consiste esto? Consiste en preguntar a cada uno: ¿cuál es tu deseo propio? Hablemos de tu deseo (...) ¡Hay que comunicarse con él, eso es todo!" 57.

Hay que comunicarse. Es lo que nos dice también Octavio Paz. La violencia es lo opuesto al lenguaje. Y la guerra sería la forma más extrema de la incomunicación y de ausencia de lenguaje. "La guerra nace de la incomunicación y busca sustituir la comunicación plural por una comunicación única: la palabra del vencedor" ${ }^{5}$. En cambio la paz es la restauración del lenguaje, lo que permite incluir también la diversidad, el conflicto. En democracia hay espacio para que retorne la comunicación: el niño, el estudiante, el marginado, la mujer, el indígena pueden empezar a ser escuchados. ¿Cuál es tu deseo propio? Hablemos de tu deseo... El niño es un ser humano más vulnerable a la violencia, como lo es hoy día también la mujer. Algunas mujeres hoy descubren a un verdugo en quien era hasta ayer su amante. Es la violencia que nos desafía por donde no esperamos.

\section{RETORNO A LAS PALABRAS}

En dictadura hubo un retroceso del derecho, a una etapa arcaica y cruel. Las familias de los muertos y desaparecidos quedaron sin respuesta a su demanda de justicia. El poder democrático naciente reconoció esta deuda y decidió otorgar un sustituto parajudicial: la Comisión Rettig. Se escuchó a las víctimas y emitió una conclusión. Este resultado no pudo ser una sentencia: fue un saber, un informe. No escuchó a los ofensores: no comparecieron. No fue posible allí reunir a las partes en conflicto frente a un tercero imparcial.

Este informe si no hace justicia, al menos reconoció oficialmente lo que había ocurrido: las violencias cometidas. La publicación de este informe fue un primer paso en un camino de reparación. Se hacía allí un archivo y un inventario doloroso. Se reconocía en voz alta los hechos antes mudos. Se había dado la palabra a quienes no la tenían: hablaron los familiares, en testimonio conmovedor, ahora reconocido a la luz del día. Fue una palabra parcialmente sanadora, pues las palabras tienen una fuerza misteriosa. Ese Informe hizo parir algo nuevo: un clima más humano. Podía nombrarse la violencia “Tú mataste a tu hermano". Tremendo, por lo menos verdadero. Desde el reconocimiento de la verdad es concebible construir un espacio común, un país común.

¿Qué ocurrió luego? Una acción violenta interrumpió las palabras recién pronunciadas, como una piedra que cae en un espejo de agua. El ruido atronador de un atentado político nos devolvió a la materia, a la animalidad. Las palabras se esfumaron: el peligro acechaba. ¿Quién puede oír la voz suave de las palabras en medio de la batahola de emociones arrolladoras: el miedo, el resentimiento? La luminosidad tranquila del informe, fue ocultada por la llama incandescente de un disparo. Victoria momentánea de la violencia.

La violencia termina cuando es posible hablar, y al revés. La palabra es lo contrario de la violencia. La violencia, en vez de hablar, hiere. Ella es muda, es un acto. El Informe

\footnotetext{
57 Idem.

58 PAZ, Octavio. Hombres en su siglo. Barcelona: Ed. Seix Barral, 1984.
} 
Rettig es el comienzo de poner palabras a la violencia. Este intento de volver a las palabras es roto por un asesinato. Una sola muerte pudo acallar en ese momento el rumor que se levantaba en el Informe, por las miles de muertes contadas en él. Es el privilegio extraño y misterioso de la violencia. La muerte de un senador permite acallar el clamor que se levantaba de mil hombres, de mil nombres. Una muerte contra mil. ¿No era el tiempo aún de las palabras?

En períodos de violencia se rompe lo que Octavio Paz llama el pacto de las palabras. La violencia es acción, que es lo contrario de la palabra. La acción violenta es característicamente muda. Es silenciosa, quiere ocultarse, al menos en parte, pues por otro lado su eficacia requiere que sea visible a la población, para conseguir intimidación. Las palabras se interrumpen con la violencia, han dejado de valer, han perdido su savia, se convierten en cáscaras vacías, en simulacros. En dictadura se produce una metamorfosis de las palabras. Para las víctimas, palabras sagradas como derecho y justicia, en la boca del poder pasan a convertirse en muecas, en gárgolas usadas como ornamento en el carro del poderoso. Con el imperio de la violencia, la palabra misma está muerta, ha cesado de existir, ha sido vaciada de su contenido. Solo queda un ruido, un sonido vacío que no significa nada real. Un levantamiento militar, un golpe, una revolución, es llamado pronunciamiento; la tortura y la muerte, es llamada violencia innecesaria, exceso (¡exceso de qué?); el homicidio es llamado enfrentamiento o ley de fuga. El poder violento aniquila la palabra y hace retroceder la historia a un nivel concreto, material, más próximo a la animalidad que al hombre. En la violencia ya no hablan las palabras: habla la acción, el gesto, la amenaza. En la violencia, las palabras se han convertido en hilos de una telaraña rota, imperando solo el huracán de la fuerza. La fuerza es como un río, un animal embravecido, una fuerza elemental que actúa y aniquila. No ciegamente, pues tiene un designio claro: el afianzamiento del poder, la inmovilización del rival, el sometimiento de la población. Pero en la violencia hay una inevitable ceguera, al menos parcial, hay algo manco. En ella hay una carencia, una torpeza radical, algo inhumano. Le falta lo más auténticamente humano: la luz de la palabra, que yace hecha añicos en el suelo.

En la violencia hay algo de tremendo, de estremecedor que se emparenta con lo divino, o tal vez, lo demoníaco. El violento, en cierto modo, usurpa una condición divina: la decisión sobre la vida o la muerte. El violento se otorga a sí mismo una facultad sagrada, actúa como si fuera omnipotente. Quita la vida o la da, como un dios. Quizá en un momento se siente como El. Sin embargo, no es más que un ídolo, un simulacro de dios, un usurpador. Extrañamente su acción es eficaz, atemoriza y finalmente impera. Es la enigmática eficacia del mal en la historia, que se teje con varios hilos, uno de ellos, la violencia.

Subsiste, sin embargo, en la violencia un esbozo de conciencia: siempre aspira presentarse como justa, necesaria, inevitable y, en definitiva, como artífice del progreso. En el fondo, aspira a justificarse como humana. La violencia ambiciona retornar a las palabras y al lenguaje. El violento se justifica, quiere tener la razón, quiere tener el derecho. Hay allí un reconocimiento implícito de la superioridad última de la razón, de la palabra. "Una violencia que habla es ya una violencia que trata de tener razón (...) y que ya comienza a negarse como violencia", ha dicho Ricoeur. Pues la violencia desnuda es muda o 
mentirosa. Y la mentira es un no lenguaje, es una trampa que funciona solo en el suelo firme de palabras verdaderas que la rodean. La mentira es un truco, es la violencia disfrazada y oculta en el espacio del lenguaje.

Cuando la violencia abandona el silencio y la mentira, es señal de que quiere volver al lenguaje, al respeto de la comunidad humana. Es la búsqueda de la tregua de las palabras, del pacto verbal. Siempre será necesario seguir hablando, incluso al precio del grito, del llanto, de la confrontación, eso sí, con palabras. La ciudad y los ciudadanos necesitamos tanto como el pan, de las palabras. Palabras vivas, palabras con derecho; palabras reaparecidas, vueltas a la vida, resucitadas.

\section{REFERENCIAS BIBLIOGRÁFICAS}

CAILlOIS, Roger. Sociología del Verdugo, en Instintos y Sociedad, Barcelona, Seix Barral, 1969.

Canetti, Elías, La conciencia de las Palabras. 1975.

Dolto, F. La causa de los niños. Barcelona, Ed. Paidós, 1990

Foucault, M. La Verdad y las formas jurídicas. México, Gedisa, 1984.

Hegel, G.W.F. Escritos de Juventud. México, Fondo de Cultura Económica, 1984.

Méndez Fetter, P. Crisis de Confianza en la Justicia, en: Revista Mensaje Vol. XXVIII, Ed. N 284, Chile, Noviembre 1979. Quien cita el discurso de inauguración del año judicial de 1975, pronunciado por el presidente de la Corte Suprema, 1978.

Moulian, Tomás. Chile actual, Anatomía de un Mito. Santiago, LOM Ediciones, 1997.

PAZ, Octavio. Hombres en su siglo. Barcelona, Ed. Seix Barral, 1984.

QueZadA, Alejandro. La lección de la DINA, en: Revista Mensaje Vol. XXVII, Ed. N 270, Chile, julio 1978. Revista Mensaje, Ed. No 250, junio, 1976.

Verdugo, P. Tiempo de días claros, los desaparecidos. Santiago, Ediciones CESOC, 1990. 
